\title{
ANALISIS MINIMALISASI BIAYA PADA PASIEN ASMA RAWAT INAP DI BEBERAPA RUMAH SAKIT KOTA SAMARINDA
}

\author{
Ade Nurlian ${ }^{1, *}$, Wisnu Cahyo Prabowo ${ }^{1}$, Jaka Fadraersada ${ }^{2}$ \\ ${ }^{1}$ Laboratorium Penelitian dan Pengembangan Kefarmasian "Farmaka Tropis", \\ Fakultas Farmasi, Universitas Mulawarman, Samarinda, Indonesia \\ ${ }^{2}$ Kelompok Bidang Ilmu Farmasi Klinik dan Komunitas, Fakultas Farmasi, \\ Universitas Mulawarman, Samarinda, Indonesia \\ *Email: adenurlian59@gmail.com
}

\begin{abstract}
Asthma is a disease characterized by inflammation of the respiratory tract that can relapse spontaneously with or without appropriate treatment. In Indonesia the national prevalence for asthma at all ages is 4.5\%. In order to reduce the number of asthma patients and reduce the mortality rate of asthma, the right and efficient drug therapy is needed, so the purpose of this study is to find out the most efficient and the minimal cost of asthma drugs in two different hospitals by pharmacoeconomic analysis. This study is an observational study with retrospective data collection with total sampling technique in hospitalized asthma patients, data was taken in several Samarinda hospitals in the period of January 2016-July 2018. Data were analyzed by Cost Minimalization Analysis (CMA) method. The results showed that the most widely used asthma medications in Hospital A and Hospital B were Combivent ${ }^{\circledR}$ and Ventolin ${ }^{\circledR}$. The analysis results of the total cost of Combivent ${ }^{\circledR}$ Rp. 6,397,140,- and Ventolin ${ }^{\circledR}$ Rp. 4,658,701,- in Hospital A, and the analysis results of the total cost of Combivent ${ }^{\circledR}$ is Rp. 3,587,072,- and Ventolin ${ }^{\circledR}$ Rp. 2.150,648,- in Hospital B. Based on the results of the study it can be concluded that, the use of Ventolin ${ }^{\circledR}$ is more efficient than Combivent ${ }^{\circledR}$ based on the CMA analysis method.
\end{abstract}

Keywords: Asthma, Cost Minimization Analysis, Pharmacoeconomics.

\begin{abstract}
ABSTRAK
Asma merupakan penyakit yang ditandai dengan adanya inflamasi pada saluran napas yang bisa kembali spontan dengan atau tanpa pengobatan yang sesuai. Di Indonesia prevalensi nasional untuk penyakit asma pada semua umur adalah 4,5\%. Agar dapat menurunkan angka penderita dan mengurang angka kematian penyakit asma, diperlukan terapi obat yang tepat dan efisien, sehingga tujuan penelitian ini adalah untuk mengetahui obat asma dengan biaya yang lebih minimal dengan menggunakan analisis farmakoekonomi. Penelitian ini merupakan studi observasional dengan pengumpulan data secara retrospektif dengan teknik total sampling, data pasien asma rawat inap diambil dari beberapa Rumah Sakit Samarinda periode Januari 2016-Juli 2018. Data dianalisis dengan metode Cost Minimalization Analysis (CMA). Hasil menunjukkan bahwa obat asma yang paling banyak digunakan di Rumah Sakit A dan di Rumah Sakit B adalah Combivent ${ }^{\circledR}$ dan Ventolin ${ }^{\circledR}$.
\end{abstract}


Hasil analisis total biaya di Rumah Sakit A dengan Combivent ${ }^{\circledR}$ Rp. 6.397.140,- dan Ventolin $^{\circledR}$ Rp. 4.658.701,- dan hasil analisis total biaya di Rumah Sakit B dengan Combivent ${ }^{\circledR}$ Rp. 3.587.072,- dan Ventolin ${ }^{\circledR}$ Rp. 2.150.648,-. Berdasarkan hasil penelitian dapat disimpulkan bahwa, penggunaan obat asma Ventolin ${ }^{\circledR}$ lebih efisien dibandingkan Combivent ${ }^{\circledR}$ berdasarkan metode analisis ekonomi CMA.

Kata Kunci: Analisis Minimalisasi Biaya, Asma, Farmakoekonomi.

DOI: https://doi.org/10.25026/mpc.v8i1.297

\section{PENDAHULUAN}

Penyakit asma disebabkan oleh reaksi hiperresponsif yang melibatkan banyak sel imun tubuh seperti mast cell, eosinofil dan T-limfosit terhadap stimulus tertentu dan menimbulkan gejala dyspnea, wheezing, dan batuk akibat obstruksi jalan napas yang bersifat reversibel dan terjadi secara episodik berulang $^{[1]}$. Di Indonesia prevalensi nasional untuk penyakit asma pada semua umur adalah $4,5 \%{ }^{[2]}$.

Agar dapat menurunkan angka penderita dan mengurangi angka kematian penyakit asma maka diperlukan terapi obat yang tepat, obat yang digunakan untuk pengobatan penyakit asma yaitu meliputi bronkodilator, antiinflamasi, antihistamin, mukolitik, antitusif dan monoklonal antibodi ${ }^{[1]}$. Banyaknya jenis obat menyebabkan sulitnya memilih obat yang efektif dari segi biaya yang dikeluarkan.

Biaya pelayanan kesehatan dapat dirasakan semakin meningkat akibat dari banyak faktor, diantaranya perubahan pola penyakit dan pola pengobatan, meningkatnya permintaan masyarakat dan perubahan ekonomi secara global. Sedangkan biaya yang tersedia untuk kesehatan belum dapat ditingkatkan, kemampuan pemerintah terbatas dan peran masyarakat masih belum maksimal. Diperlukan pemikiran dalam penggunaan dana secara lebih rasional ${ }^{[3]}$.

$$
\text { Oleh karena itu dilakukan }
$$
penelitian analisis ekonomi kesehatan yang disebut Analisis minimalisasi biaya atau Cost Minimization Analysis (CMA) yang mana teknik analisis ekonomi kesehatan untuk membandingkan dua atau lebih pilihan obat yang memberikan hasil kesehatan yang setara ${ }^{[4]}$.

Farmakoekonomi sebagai alat dalam peningkatan efisiensi dan memobilisasi sumber dana dapat dipergunakan untuk membantu mengembangkan pemikiran-pemikiran khusus tanpa mengabaikan aspek-aspek sosial dari sektor kesehatan itu sendiri ${ }^{[3]}$.

\section{METODOLOGI}

\section{Metode dan Jenis Penelitian}

Penelitian ini merupakan penelitian observational, non-eksperimental dengan rancangan deskriptif dengan data retrospektif yang bersumber dari data rekam medik pasien rawat inap penderita penyakit asma, serta daftar biaya terapi dari bagian keuangan Rumah Sakit.

\section{Populasi dan Sampel}

Teknik penentuan sampel yaitu secara total sampling, dimana sampel penelitian yaitu semua populasi pasien rawat inap penderita asma di Rumah Sakit periode Januari 2016-Juli 2018.

\section{Pengambilan Data}

Data yang diambil meliputi identitas pasien, diagnosis, obat asma yang digunakan, ruang perawatan serta lama perawatan pasien di Rumah Sakit, harga 
obat, biaya laboratorium dan biaya rawat inap. Pengambilan data ini selain diruang rekam medik, data diambil di ruangan keuangan Rumah Sakit.

\author{
Analisis Data \\ CMA adalah teknik analisis untuk \\ membandingkan dua atau lebih pilihan \\ yang memberikan hasil kesehatan yang \\ setara. Rumus CMA yaitu: \\ Direct Cost + Indirect Cost
}

\section{HASIL DAN PEMBAHASAN}

Tabel 1. Karakteristik Pasien Asma Berdasarkan Jenis Kelamin

\begin{tabular}{ccccc}
\hline Jenis & \multicolumn{2}{c}{ Rumah Sakit A } & \multicolumn{2}{c}{ Rumah Sakit B } \\
\cline { 2 - 5 } Kelamin & Jumlah & $\%$ & Jumlah & $\%$ \\
\hline Laki-laki & 12 & $57 \%$ & 7 & $58 \%$ \\
Perempuan & 9 & $43 \%$ & 5 & $42 \%$ \\
\hline
\end{tabular}

Tabel 2. Karakteristik Pasien Asma Berdasarkan Usia

\begin{tabular}{ccccc}
\hline \multirow{2}{*}{$\begin{array}{c}\text { Usia } \\
\text { tahun })\end{array}$} & \multicolumn{2}{c}{ Rumah Sakit A } & \multicolumn{2}{c}{ Rumah Sakit B } \\
\cline { 2 - 5 } & Jumlah & $\%$ & Jumlah & $\%$ \\
\hline $0-5$ & 1 & 4,76 & 1 & 8,33 \\
$6-11$ & 2 & 9,52 & 0 & 0 \\
$12-25$ & 3 & 14,29 & 1 & 8,33 \\
$26-45$ & 2 & 9,25 & 5 & 41,67 \\
$46-59$ & 3 & 14,29 & 3 & 25,00 \\
$60-74$ & 10 & 47,62 & 2 & 16,67 \\
\hline Total & 21 & 100 & 12 & 100 \\
\hline
\end{tabular}

Tabel 3. Obat Asma yang Paling Sering Digunakan di Rumah Sakit

\begin{tabular}{cccccc}
\hline Nama & Rute & \multicolumn{2}{c}{ Rumah Sakit A } & \multicolumn{2}{c}{ Rumah Sakit B } \\
\cline { 3 - 6 } Obat & Pemberian & Jumlah & $\%$ & Jumlah & $\%$ \\
\hline Combivent $^{\circledR}$ & Inhalasi & 15 & $71 \%$ & 3 & $25 \%$ \\
Ventolin $^{\circledR}$ & Inhalasi & 6 & $29 \%$ & 9 & $75 \%$ \\
\hline
\end{tabular}

Berdasarkan Tabel 1, jenis kelamin laki-laki lebih banyak menderita penyakit asma dibandingkan dengan perempuan. Ketika kanak-kanak sensitivitas terhadap serangan asma lebih tinggi pada anak laki-laki dibandingkan anak perempuan dikarenakan diameter saluran napas anak laki-laki yang lebih lebih kecil sehingga mereka lebih sensitif dan peka apabila terjadi penyumbatan pada saluran napas ${ }^{[1]}$.

Namun ketika dewasa prevalensi asma lebih besar terjadi pada perempuan disebabkan oleh kadar esterogen yang beredar dalam tubuh dapat meningkatkan proses degranulasi eosinofil sehingga memudahkan terjadinya serangan asma. Kadar esterogen yang tinggi dapat 
berperan sebagai pemicu inflamasi terutama mempengaruhi sel mast, dimana sel mast merupakan sel yang berperan dalam memicu reaksi hipersensitifitas dengan melepaskan histamin dan mediator inflamasi lainnya, sehingga memperberat morbiditas asma pada pasien asma $^{[5]}$.

Selain faktor internal, faktor eksternal seperti asap rokok merupakan salah satu pencetus terjadinya asma, dimana sebagian besar perokok adalah jenis kelamin laki-laki. Merokok dapat menyebabkan penurunan fungsi paru yang cepat, meningkatkan derajat keparahan asma, menjadikan penderita kurang responsif terhadap glukokortikosteroid. Glukokortikosteroid dengan dosis rendah merupakan first line untuk mengkontrol asma dan apabila pasien asma kurang responsif terhadap glukokortikosteroid maka dapat menurunkan tingkat kontrol penyakit asma dan dapat memperparah penyakit ${ }^{[6]}$.

Berdasarkan Tabel 2 asma bisa diderita oleh semua golongan usia, baik muda ataupun tua, karena faktor genetik merupakan salah satu faktor terjadinya asma pada seseorang. Tetapi berdasarkan data yang didapat, kejadian asma cenderung terjadi pada usia 26-74 tahun.

Semakin bertambahnya usia maka semakin menurunnya fungsi paru-paru yaitu elastisitas dan aktivitas pembersihan paru-paru akan berkurang. Akibatnya, jumlah oksigen yang dapat ditampung semakin berkurang, demikian pula dengan refleks batuk. Hal tersebut yang terjadi pada penderita asma usia lanjut ( $\geq 60$ tahun) [6].

Pasien asma usia produktif (12-59 tahun) akan aktif dalam keseharian dan mudah terpapar faktor-faktor lingkungan seperti debu, asap rokok, asap kendaraan, bulu binatang dan juga stress psikologis yang dapat menunjukkan hubungan timbal balik antara faktor periferal yang meregulasi reaksi inflamasi dan respon saraf pusat terkait stress dan reaktivitas emosi. Emosi dan perasaan seperti khawatir, cemas, takut, dan panik, dapat menyebabkan ketegangan muskuler dan kontraksi di sekitar bronkiolus, sehingga bronkiolus menjadi lemah dan kejang. Ekspresi emosi yang ekstrim dapat menyebabkan hiperventilasi dan hipokapnia, yang dapat menyebabkan penyempitan jalan nafas ${ }^{[6]}$.

Berdasarkan Tabel 3 hasil penggunaan obat pada pasien asma di beberapa Rumah Sakit di Samarinda periode Januari 2016 - Juli 2018. Rumah Sakit A menunjukkan bahwa persentase Combivent ${ }^{\circledR}$ sebesar $71 \%$ dan Ventolin ${ }^{\circledR}$ sebesar 29\%. Sedangkan Rumah Sakit B menunjukkan bahwa persentase Combivent $^{\circledR}$ sebesar 25\% dan Ventolin ${ }^{\circledR}$ sebesar $75 \%$.

Pada Rumah Sakit A pasien banyak menggunakan Combivent ${ }^{\circledR} \quad$ daripada Ventolin $^{\circledR}$ hal tersebut karena pasien Rumah Sakit A merupakan pasien swadana. Sedangkan Rumah Sakit B pasien lebih banyak menggunakan Ventolin ${ }^{\circledR}$ daripada Combivent ${ }^{\circledR}$ karena pasien Rumah Sakit B merupakan pasien yang menggunakan asuransi penjamin. Diketahui harga Combivent ${ }^{\circledR}$ Rp. 224.400.lebih mahal daripada Ventolin ${ }^{\circledR}$ yaitu Rp. 130.000,-

Combivent $^{\circledR}$ merupakan obat kombinasi antara ipratropium bromida dengan albuterol sulfat, sedangkan Ventolin ${ }^{\circledR}$ merupakan obat tunggal yang berisikan albuterol sulfat. Mekanisme kerja dari ipratropium bromide adalah merupakan obat antikolinergik yang bekerja menghambat asetilkolin pada reseptor kolinergik yang memblok asetilkolin di saraf parasimpatetik otot bronkus, menyebabkan stimulasi guanyl cyclase dan menekan peningkatan cGMP (mediator bronkokontriksi) sehingga menimbulkan bronkodilatasi. Mekanisme kerja dari albuterol sulfat atau yang biasa dikenal di Indonesia sebagai salbutamol adalah merupakan simpatomimetik termasuk golongan beta-adrenergik agonist yang memiliki efek secara khusus terhadap reseptor beta(2)-adrenergik yang terdapat 
didalam adenyl cyclase. Adenyl cyclase merupakan katalis dalam proses perubahan adenosine triphosphate (ATP) menjadi cyclic-3', 5'-adenosine monophosphate (cyclic AMP). Meningkatnya jumlah cyclic $A M P$ yang berdampak pada relaksasi otot polos bronkial serta menghambat pelepasan mediator penyebab reaksi hipersensitivitas dari sel mast.
Bila dibandingkan, penggunaan Combivent ${ }^{\circledR}$ dengan Ventolin ${ }^{\circledR}$ maka akan lebih baik bila menggunakan Combivent ${ }^{\circledR}$ karena merupakan obat kombinasi ipratropium bromida dengan albuterol sulfat yang diharapkan dapat lebih cepat menangani asma dibandingkan Ventolin ${ }^{\circledR}$ yang obat tunggal dengan zat aktif albuterol sulfat.

Tabel 4. Analisis Minimalisasi Biaya Penggunaan Obat Combivent ${ }^{\circledR}$ di Rumah Sakit A

\begin{tabular}{|c|c|c|c|c|c|c|c|c|c|}
\hline \multirow[b]{2}{*}{ No } & \multirow[b]{2}{*}{ LOS } & \multicolumn{6}{|c|}{ Direct Cost } & \multirow{2}{*}{$\begin{array}{c}\text { Indirect } \\
\text { Cost }\end{array}$} & \multirow[b]{2}{*}{ CMA } \\
\hline & & Farmasi & $\begin{array}{c}\text { Jasa } \\
\text { Pelayanan }\end{array}$ & Tindakan & BHP & Kamar & $\begin{array}{c}\text { Total Direct } \\
\text { Cost }\end{array}$ & & \\
\hline 1. & 1 & 565,675 & 836,683 & 866,768 & 540,480 & 150,000 & $2,959,606$ & 106,730 & $3,066,336$ \\
\hline 2. & 2 & 856,554 & 841,833 & 816,618 & 457,000 & 300,000 & $3,272,005$ & 231,460 & $3,503,465$ \\
\hline 3. & 3 & $1,875,770$ & $2,612,366$ & $1,668,822$ & 508,000 & 450,000 & $7,114,958$ & 320,190 & $7,435,148$ \\
\hline 4. & 1 & $1,341,640$ & $1,633,403$ & $1,442,660$ & 504,480 & 150,000 & $5,072,183$ & 106,730 & $5,178,913$ \\
\hline 5. & 4 & $2,819,310$ & $3,812,705$ & $4,384,095$ & $3,146,400$ & 600,000 & $14,762,510$ & 426,920 & $15,189,430$ \\
\hline 6. & 4 & $1,788,981$ & $2,698,596$ & $1,877,393$ & 794,600 & 600,000 & $7,759,570$ & 426,920 & $8,186,490$ \\
\hline 7. & 4 & 700,931 & $2,102,738$ & $2,686,013$ & 768,500 & 600,000 & $6,858,182$ & 426,920 & $7,285,102$ \\
\hline 8. & 7 & 379,758 & $1,261,388$ & $1,429,363$ & 723,900 & $1,050,000$ & $4,844,409$ & 747,110 & $5,591,519$ \\
\hline 9. & 3 & 437,556 & $1,012,875$ & $1,128,125$ & 345,500 & 450,000 & $3,374,056$ & 320,190 & $3,694,246$ \\
\hline 10. & 9 & 869,730 & $2,485,788$ & $2,075,963$ & $1,980,980$ & $1,350,000$ & $8,762,461$ & 960,570 & $9,723,031$ \\
\hline 11. & 2 & $1,619,545$ & $1,084,866$ & 677,322 & 269,400 & 300,000 & $3,951,133$ & 231,460 & $4,182,593$ \\
\hline 12. & 2 & $2,116,580$ & $1,712,825$ & $1,639,675$ & 613,980 & 300,000 & $6,383,060$ & 231,460 & $6,614,520$ \\
\hline 13. & 2 & $2,383,971$ & $1,353,138$ & $1,173,613$ & 324,700 & 300,000 & $5,535,422$ & 231,460 & $5,766,882$ \\
\hline 14. & 2 & $1,166,680$ & $1,455,416$ & 973,772 & 331,400 & 300,000 & $4,227,268$ & 231,460 & $4,458,728$ \\
\hline 15. & 3 & $1,518,851$ & $1,700,488$ & $1,467,763$ & 623,400 & 450,000 & $5,760,502$ & 320,190 & $6,080,692$ \\
\hline & $\sum$ & $20,441,532$ & $26,605,108$ & $24,307,965$ & $11,932,720$ & $7,350,000$ & $90,637,325$ & $5,319,770$ & $95,957,095$ \\
\hline \multicolumn{9}{|c|}{ CMA Perpasien } & 6,397,139.667 \\
\hline
\end{tabular}

Tabel 5. Analisis Minimalisasi Biaya Penggunaan Obat Ventolin ${ }^{\circledR}$ di Rumah Sakit A

\begin{tabular}{|c|c|c|c|c|c|c|c|c|c|}
\hline \multirow[b]{2}{*}{ No } & \multirow[b]{2}{*}{ LOS } & \multicolumn{6}{|c|}{ Direct Cost } & \multirow{2}{*}{$\begin{array}{c}\text { Indirect } \\
\text { Cost }\end{array}$} & \multirow[b]{2}{*}{ CMA } \\
\hline & & Farmasi & $\begin{array}{c}\text { Jasa } \\
\text { Pelayanan }\end{array}$ & Tindakan & BHP & Kamar & $\begin{array}{c}\text { Total Direct } \\
\text { Cost }\end{array}$ & & \\
\hline 1. & 2 & 297,701 & 861,528 & 960,623 & 623,500 & 300,000 & $3,043,352$ & 231,460 & $3,274,812$ \\
\hline 2. & 1 & $1,037,307$ & 888,638 & 728,113 & 114,000 & 150,000 & $2,918,058$ & 106,730 & $3,024,788$ \\
\hline 3. & 5 & $2,034,023$ & $1,915,278$ & $1,411,660$ & 582,480 & 750,000 & $6,693,441$ & 533,650 & $7,227,091$ \\
\hline 4. & 5 & 647,841 & $1,380,188$ & $1,412,563$ & 808,480 & 750,000 & $4,999,072$ & 533,650 & $5,532,722$ \\
\hline 5. & 2 & $1,204,995$ & $1,575,969$ & $1,285,282$ & 462,900 & 300,000 & $4,829,146$ & 231,460 & $5,060,606$ \\
\hline 6. & 2 & 800,705 & $1,194,500$ & $1,039,125$ & 266,400 & 300,000 & $3,600,730$ & 231,460 & $3,832,190$ \\
\hline \multicolumn{2}{|c|}{$\sum$} & $6,022,572$ & $7,816,101$ & $6,837,366$ & $2,857,760$ & $2,550,000$ & $26,083,799$ & $1,868,410$ & $27,952,209$ \\
\hline \multicolumn{9}{|c|}{ CMA Perpasien } & $4,658,701.5$ \\
\hline
\end{tabular}

Tabel 6. Analisis Minimalisasi Biaya Penggunaan Obat Combivent ${ }^{\circledR}$ di Rumah Sakit B

\begin{tabular}{|c|c|c|c|c|c|c|c|c|c|}
\hline \multirow[b]{2}{*}{ No } & \multirow[b]{2}{*}{ LOS } & \multicolumn{6}{|c|}{ Direct Cost } & \multirow[b]{2}{*}{$\begin{array}{c}\text { Indirect } \\
\text { Cost }\end{array}$} & \multirow[b]{2}{*}{ CMA } \\
\hline & & Farmasi & $\begin{array}{c}\text { Jasa } \\
\text { Pelayanan }\end{array}$ & Tindakan & BHP & Kamar & $\begin{array}{c}\text { Total Direct } \\
\text { Cost }\end{array}$ & & \\
\hline 1. & 6 & $1,073,716$ & 170,000 & $1,286,300$ & 60,500 & 405,000 & $2,995,516$ & 666,850 & $3,662,366$ \\
\hline 2. & 5 & 657,928 & 145,000 & $1,053,506$ & 63,500 & 337,500 & $2,257,434$ & 554,875 & $2,812,309$ \\
\hline 3. & 5 & 760,041 & 220,000 & $1,758,625$ & 655,500 & 337,500 & $3,731,666$ & 554,875 & $4,286,541$ \\
\hline & $\sum$ & $2,491,685$ & 535,000 & $4,098,431$ & 779,500 & $1,080,000$ & $8,984,616$ & $1,776,600$ & $10,761,216$ \\
\hline \multicolumn{9}{|c|}{ CMA Perpasien } & $3,587,072$ \\
\hline
\end{tabular}


Tabel 7. Analisis Minimalisasi Biaya Penggunaan Obat Ventolin ${ }^{\circledR}$ di Rumah Sakit B

\begin{tabular}{|c|c|c|c|c|c|c|c|c|c|}
\hline \multirow[b]{2}{*}{ No } & \multirow[b]{2}{*}{ LOS } & \multicolumn{6}{|c|}{ Direct Cost } & \multirow[b]{2}{*}{$\begin{array}{l}\text { Indirect } \\
\text { Cost }\end{array}$} & \multirow[b]{2}{*}{ CMA } \\
\hline & & Farmasi & $\begin{array}{c}\text { Jasa } \\
\text { Pelayanan }\end{array}$ & Tindakan & BHP & Kamar & $\begin{array}{c}\text { Total Direct } \\
\text { Cost }\end{array}$ & & \\
\hline 1. & 3 & 616,271 & 95,000 & 602,000 & 30,500 & 202,500 & $1,546,271$ & 333,925 & $1,880,196$ \\
\hline 2. & 1 & 586,644 & 125,000 & 437,000 & 21,500 & 67,500 & $1,237,644$ & 110,975 & $1,348,619$ \\
\hline 3. & 4 & 703,249 & 120,000 & 257,000 & 35,500 & 270,000 & $1,385,749$ & 443,900 & $1,829,649$ \\
\hline 4. & 3 & 532,475 & 150,000 & $1,111,825$ & 205,000 & 202,500 & $2,201,800$ & 333,925 & $2,535,725$ \\
\hline 5. & 2 & 432,458 & 100,000 & 538,500 & 68,500 & 135,000 & $1,274,458$ & 221,950 & $1,496,408$ \\
\hline 6. & 2 & 493,502 & 100,000 & 573,950 & 25,000 & 135,000 & $1,327,452$ & 221,950 & $1,549,402$ \\
\hline 7. & 2 & 436,340 & 125,000 & 824,650 & 453,000 & 135,000 & $1,973,990$ & 221,950 & $2,195,940$ \\
\hline 8. & 3 & 658,522 & 150,000 & 739,500 & 23,500 & 202,500 & $1,774,022$ & 333,925 & $2,107,947$ \\
\hline 9. & 6 & $1,448,897$ & 215,000 & $1,626,700$ & 49,500 & 405,000 & $3,745,097$ & 666,850 & $4,411,947$ \\
\hline & & $5,908,358$ & $1,180,000$ & $6,711,125$ & 912,000 & $1,755,000$ & $16,466,483$ & $2,889,350$ & 19,355,833 \\
\hline \multicolumn{9}{|c|}{ CMA Perpasien } & $2,150,648.111$ \\
\hline
\end{tabular}

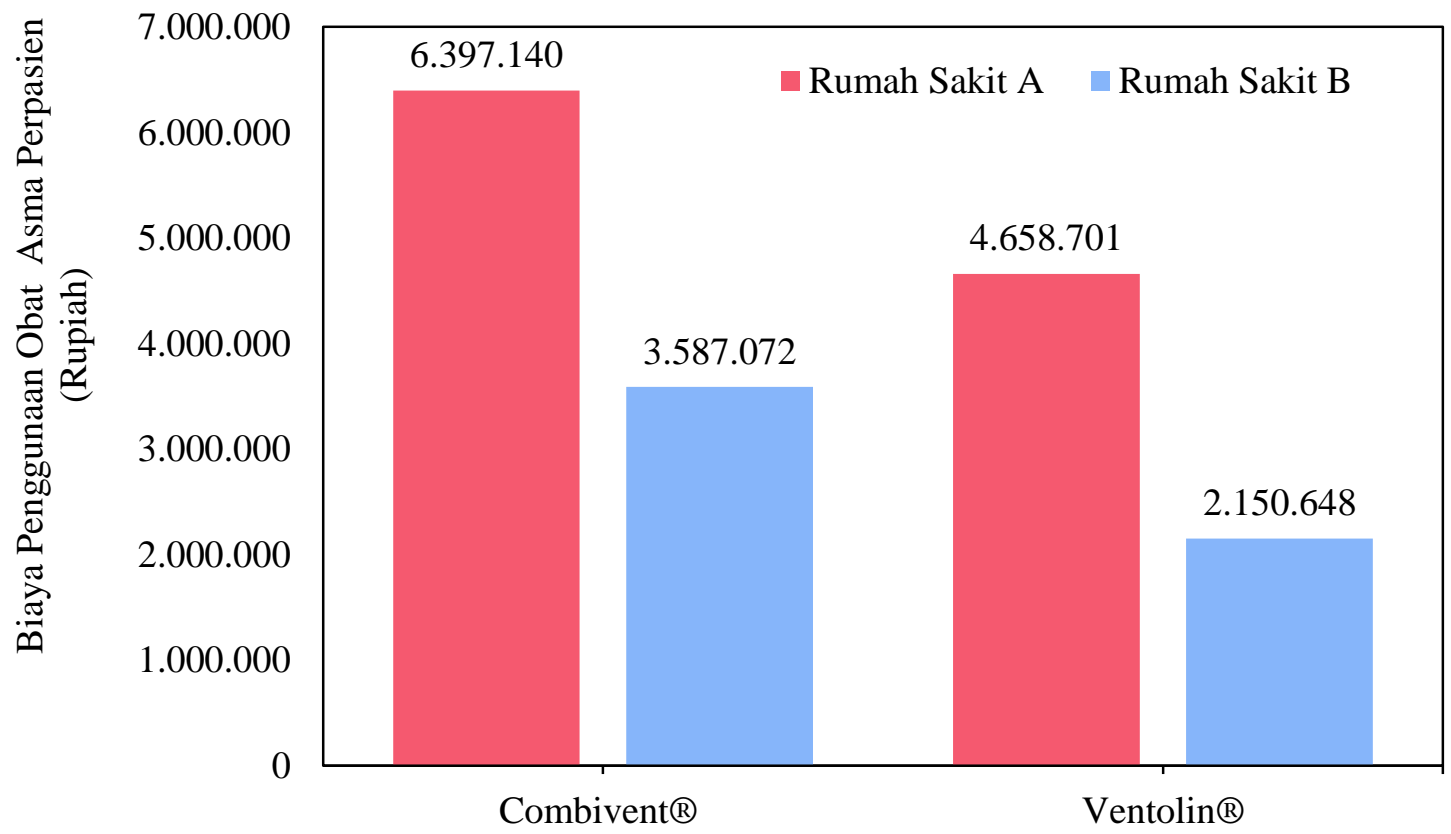

Gambar 1 Diagram Perbandingan Obat Asma dengan Biaya yang Lebih Minimal

Untuk mengetahui obat asma dengan biaya yang lebih minimal digunakan metode analisis farmakoekonomi CMA. Dalam CMA dilakukan penentuan biaya langsung (direct cost) dan biaya tidak langsung (indirect cost). Rata-rata total biaya diperoleh dengan menjumlahkan biaya langsung dan biaya tidak langsung dan dibagi dengan jumlah pasien masingmasing obat untuk dibandingkan obat asma manakah yang paling minimal biayanya.
Dari Gambar 1 diketahui bahwa obat asma dengan biaya paling minimal di Rumah Sakit A adalah Ventolin ${ }^{\circledR}$ dengan rata-rata total biaya yaitu $\mathrm{Rp}$. 4.658.701,- dibandingkan Combivent ${ }^{\circledR}$ yaitu Rp. 6.397.140,-. Dan diketahui bahwa obat asma dengan biaya paling minimal di Rumah Sakit B adalah Ventolin ${ }^{\circledR}$ dengan rata-rata total biaya yaitu Rp. 2.150.648,- dibandingkan Combivent ${ }^{\circledR}$ yaitu Rp. 3.587.072,- 


\section{KESIMPULAN}

Berdasarkan hasil penelitian yang didapatkan, maka kesimpulan dari penelitian ini adalah jenis kelamin lakilaki dan usia 26-74 tahun lebih banyak sebagai penderita asma, obat asma yang terbanyak digunakan yaitu Combivent ${ }^{\circledR}$ dan Ventolin ${ }^{\circledR}$ dan obat asma dengan biaya paling minimal hasil analisis farmakoekonomi CMA yaitu Ventolin ${ }^{\circledR}$.

\section{DAFTAR PUSTAKA}

[1]. GINA, 2016. Global Strategy for Asthma Management and Prevention.

[2]. Riset Kesehatan Dasar, 2013. Badan Penelitian dan Pengembangan Kesehatan Kementerian RI tahun 2013.
[3]. Mills, A., and Gilson, L. 1990. Ekonomi Kesehatan untuk Negara Sedang Berkembang Sebuah Pengantar. Diterjemahkan oleh Unit Analisa Kebijaksanaan dan Ekonomi Kesehatan. Biro Perencanaan Departemen Kesehatan, Jakarta.

[4]. Kemenkes RI, 2013. Pedoman Penerapan Kajian Farmakoekonomi Direktorat Jenderal Bina Kefarmasian dan Alat Kesehatan. Kementrian Kesehatan Republik Indonesia, Jakarta.

[5]. Wahyuni, Anyta Hera, 2014. Prevalensi Faktor-Faktor Pencetus Serangan Asma pada Pasien Asma di Salah Satu Rumah Sakit di Jakarta. FIK UI, Jakarta.

[6]. Nursalam, 2009. Faktor Risiko Asma dan Perilaku Pencegahan Berhubungan dengan Tingkat Kontrol Penyakit Asma. Jurnal Ners Vol.4 No.1 April 2009: 9-18. 